\title{
Processing of submicron $\alpha$-alumina powders doped with Mg-physical and chemical characterization
}

\author{
M. FILAL, D. MONCEAU, G. PETOT-ERVAS, C. PETOT and J.G. ZAO \\ CNRS-LPCM/UPR-211, Université Paris XIII, 93430 Villetaneuse, France
}

\begin{abstract}
This work examines the influence of the thermal treatment conditions at $\mathrm{T}>1150^{\circ} \mathrm{C}$, on the microstructure and microchemistry of submicron $\alpha$-alumina powders doped with '500 and 1650 ppm by weight of MgO. The powders have been characterized by XPS, TEM, SEM, BET surface area measurements and chemical analysis. Quantitative XPS analysis show a strong segregation of $\mathrm{Mg}$ at the near surface of the grains. The determining factor is the size of the grains and it has been possible to relate the amount of $\mathrm{Mg}$ at the periphery of the grains to the BET surface area measurements.
\end{abstract}

\section{I-INTRODUCTION}

The Mg-doped $\alpha$-alumina powders studied in the present work have been prepared from the alum. This paper details the effect of the last thermal treatment at $\mathrm{T}>1150^{\circ} \mathrm{C}$ on the physical and chemical characteristics of the material. The powders have been characterized by BET surface area measurements, XPS, SEM, MET and chemical analysis.

\section{II-MATERIALS}

In the alum route the dopants are added before the decomposition of the hydroxides which occurs at approximately $300^{\circ} \mathrm{C}$. This gives a uniform distribution of the dopants in the amorphous alumina powder. The next calcination occurs at temperature higher than $1150^{\circ} \mathrm{C}$. It allows to obtain the $\alpha$-alumina submicron powder $(1,2)$. This thermal treatment has been performed in large silica crucibles $(20 \mathrm{~cm}$ diameter and $15 \mathrm{~cm}$ high) or in smaller alumina crucibles $(3 \mathrm{~cm}$ diameter and $10 \mathrm{~cm}$ high). $\mathrm{Pt} / \mathrm{Pt}-10 \% \mathrm{Rh}$ thermocouples are placed in the powder to monitor its thermal history at different positions ${ }^{(3,4)}$. As an example, Fig. 1 shows variation in the calcining schedule for the powder in the silica crucible. Powders from position 6 and 7 have the largest 


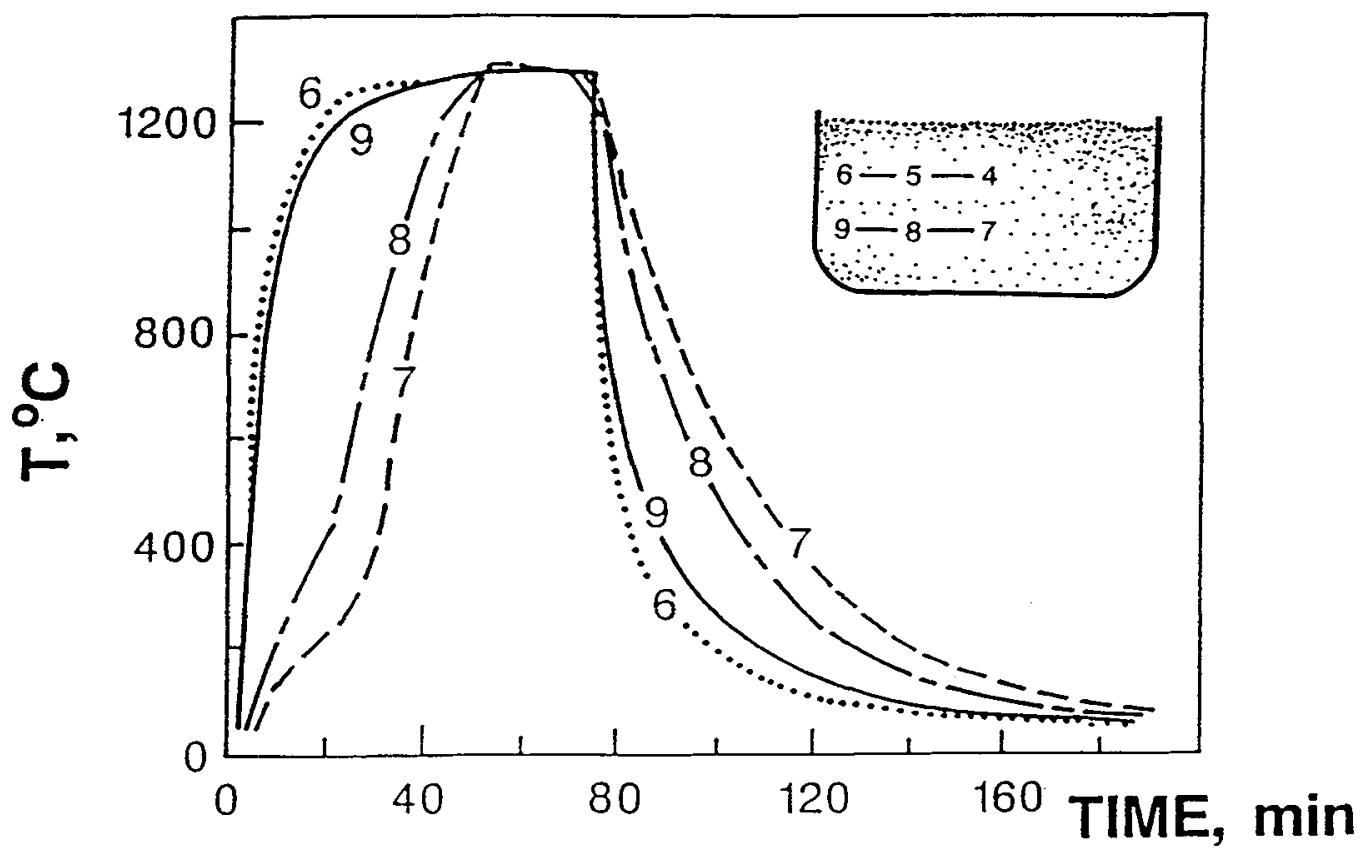

Figure 1- Thermal treatment of powders at different positions in the silica crucible.

\section{III-RESULTS AND DISCUSSION}

Chemical analysis, BET surface area measurements, SEM and TEM observations.

The main impurities found in the powder are $\mathrm{K}(13 \mathrm{ppm}$ by wt), $\mathrm{Ca}(<10 \mathrm{ppm}), \mathrm{Fe}(<10$ ppm), $\mathrm{Na}$ and $\mathrm{Si}$. The amount of $\mathrm{Si}$ (19 ppm to $63 \mathrm{ppm}$ ) and $\mathrm{Na}$ (5 ppm to $22 \mathrm{ppm}$ ) depends on the thermal treatment conditions and of the position of the powder in the silica crucible.

The BET analysis and SEM observations show that the size of the $\alpha$-alumina particles increases both with the annealing time and cooling rates. Furthermore, for the same thermal treatment conditions the BET specific surface area of the powder increases with the amount of $\mathrm{Mg}$ and $\mathrm{Si}$. The grains have generally elongated forms. Their size is included between 50 and $400 \mathrm{~nm}$. Whathever the thermal treatment conditions of the powder, the TEM observations show that the microstructure of the powder is very similar. The calcination is generally accompanied by a coarsening and sintering of the particles which leads to complex grain shapes and in some grains nanometer scale porosity. A texture has been observed at the surface of some grains which may be due to spinel precipitates. 


\section{Nano-chemical analysis}

XPS analysis show a strong surface segregation of $\mathrm{Mg}$ at the periphery of the grains. (Table 1). It has been calculated from the $\mathrm{Mg}_{1 \mathrm{~s}}, \mathrm{Mg}_{2 \mathrm{~s}}$ and $\mathrm{Mg}_{2 \mathrm{p}}$ peaks ${ }^{(2-4)}$. XPS also detected the presence of $\mathrm{Na}$ in the surface region of the grains. The level of $\mathrm{Na}$ at the periphery of the particles is higher $(1.4 \mathrm{at} \%)$ in powder from position 7 than in powder from position $6(0.6$ at.\%), in agreement with the chemical analysis .

\begin{tabular}{|c|c|c|c|}
\hline $\begin{array}{c}\text { Sample and position } \\
\text { in the crucible }\end{array}$ & $\mathrm{Mg} 1 \mathrm{~s}$ & $\mathrm{Mg} \mathrm{2s}$ & $\mathrm{Mg} 2 \mathrm{p}$ \\
\hline $\mathrm{Al}_{2} \mathrm{O}_{3} 1650 / 6$ & $\mathbf{4 , 7}$ & $\mathbf{1 , 0}$ & $\mathbf{0 , 9}$ \\
\hline $\mathrm{Al}_{2} \mathrm{O}_{3} 1650 / 7$ & $\mathbf{4 , 4}$ & $\mathbf{1 , 0}$ & $\mathbf{1 , 0}$ \\
\hline $\mathrm{Al}_{2} \mathrm{O}_{3} 550 / 6$ & $\mathbf{3 , 4}$ & $\mathbf{1 , 0}$ & $\mathbf{0 , 7}$ \\
\hline $\mathrm{Al}_{2} \mathrm{O}_{3} 550 / 7$ & $\mathbf{2 , 4}$ & $\mathbf{0 , 6}$ & $\mathbf{0 , 5}$ \\
\hline
\end{tabular}

Table 1- Amount of magnesium (at\%) determined by XPS at the near surface of the alumina powder treated in a silica crucible (position 6 and 7).

In Fig. 2 we report the main concentration of $\mathrm{Mg}$ in a depth of $2.0 \mathrm{~nm}\left(\mathrm{Mg}_{2 \mathrm{~s}}\right)$ as a function of the mean concentration in a depth of $0.5 \mathrm{~nm}\left(\mathrm{Mg}_{1 \mathrm{~s}}\right)$. The data exhibit a straight line whose slope is equal to the ratio of the analysis depth (1/4). This result suggests that $\mathrm{Mg}$ segregated mainly on a depth lower or equal to $0.5 \mathrm{~nm}$. This result is in agreement with the estimate of the repartition of $\mathrm{Mg}$ in the grains (Fig.3) taking into account the amount of $\mathrm{Mg}$ in the powder and the XPS results.

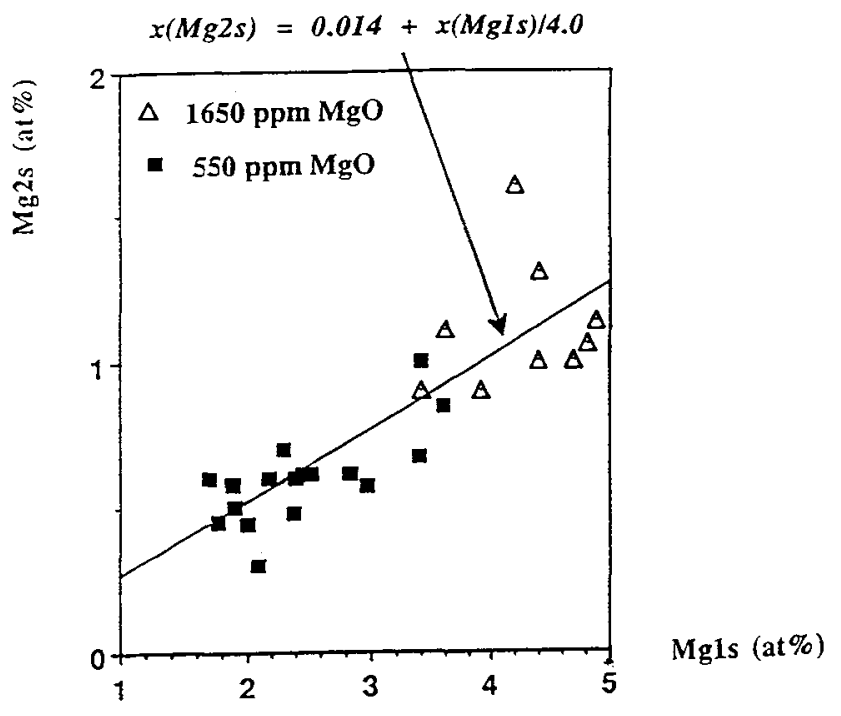

Figure 2- Concentration of magnesium in a depth of $2.0 \mathrm{~nm}\left(\mathrm{Mg}_{2 \mathrm{~s}}\right)$ as a function of the concentration in a depth of $0.5 \mathrm{~nm}\left(\mathrm{Mg}_{\mathrm{ls}}\right)$. 

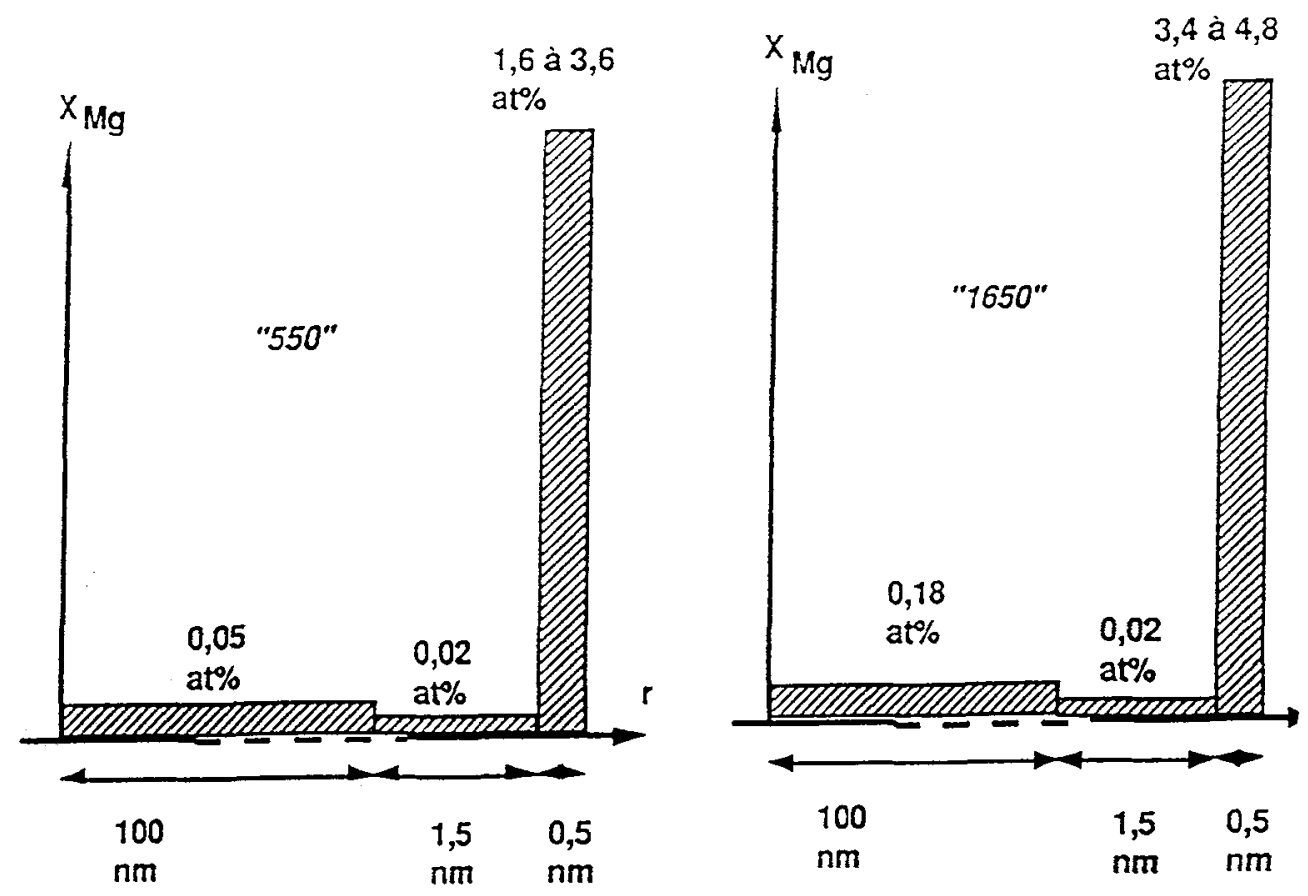

Figure 3- Distribution profile of magnesium through an alumina grain treated at $1300^{\circ} \mathrm{C}$, for both $550 \mathrm{ppm}$ and $1650 \mathrm{ppm} \mathrm{MgO}$-doped powders.

ACKNOWLEDGEMENTS : This work has been sponsored by the "Ministère de la Recherche et de la Technologie-département Matière et Matériaux", contract $\mathrm{N}^{\circ} 90$ A 0220 . The authors are indebted to J.C.Droguet and L.Du Repaire (Baikowski-Chimie, Annecy), I.Sproule and M.Graham (CNRC, Ottawa) for their collaboration and fruitful discussions.

\section{REFERENCES}

1- C.Petot, G.Petot-Ervas, D.Monceau, M.K.Loudjani, P.Rowley, I.Sproule, D.Mitchell and M.Graham, J.Annuelles du Groupe Français de Céramique (1992).

2- G.Petot-Ervas, S.Lartigue, C.Severac, M.Barj and C.Petot, Structural Ceramics, Ed. J.J.Bentzen, J.B.Sorensen, N.Christiansen and B.Ralph,(Riso National Laboratory), 459 (1990).

3- D.Monceau, G.Petot-Ervas, C.Petot, J.Fraser, I.Sproule, M.Graham, J.Eur. Cer. Soc. , to be published

4- D.Monceau, thesis Université Paris XIII 1992 